\title{
Formation of Orthographic Competence in Future Primary School Teachers during Language Training in Higher Education Institutions
}

\author{
Svitlana Ivanivna Yakymenko*, Tatyana Mykolayivna Bilyavska, Alla Anatolievna Tymchenko \\ Department of Primary Education, Mykolaiv V.O. Sukhomlynskyi National University, Ukraine
}

Received May 18, 2020; Revised June 24, 2020; Accepted July 20, 2020

Copyright $\subseteq 2020$ by authors, all rights reserved. Authors agree that this article remains permanently open access under the terms of the Creative Commons Attribution License 4.0 International License

\begin{abstract}
The article is dedicated to the orthographic competence of future primary school teachers. The purpose of the study is to develop and test the model of orthographic literacy formation in future primary school teachers, as well as define the pedagogical conditions that facilitate the efficient operation of the model in the context of the educational process in a higher education institution. The study utilizes the competency-based approach, the systemic approach and the linguodidactic approach. Through the competency-based, systemic and linguodidactic approaches, the theoretical-methodological strategy for forming the orthographic competence in future primary school teachers has been defined. The model of developing this component of linguistic competence has been developed and tested. A set of pedagogical conditions that ensure the efficient operation of this model has been experimentally tested. During the analysis of the scientific-methodological literature, the features of forming the orthographic competence in future primary school teachers have been defined. As a result of the experimental work, it has been proven that the implementation of the developed model and the adherence to certain pedagogical conditions facilitate the formation of orthographic competence in future primary school teachers. The experiment has proven that certain pedagogical conditions are efficient and the created model of orthographic literacy formation in future primary school teachers ensures the readiness to use the theoretical material in practice as well as the consistent motivation for further learning.
\end{abstract}

Keywords Professional Education, Quality of Education, Linguistic Competence, Orthographic Competence, Future Teacher, Primary School

\section{Introduction}

The formation of essential competences and the creation of efficient methods for their implementation are currently among the efficient ways to update the content of education (Rashkevich, 2014). In this context, it is important to mention the research by scholars V. Belyaev, M. Vashulenko, N. Golub, A. Goroshkina, T. Donchenko, S. Karaman, K. Klimova, I. Kochan, L. Kravets, V. Melnichaiko, N. Ostapenko, L. Ponomar, M. Pentilyuk, Yu. Rashkevich, L. Skuratovskii, L. Struganets, G. Shelekhova and others.

An integral part of future specialists' high-quality training is linguistic education that is a fundamental element in the system of universal and special competences of a future teacher, and especially a primary school teacher. After all, it is their professional activity that determines the formation (at the early stage) of students' key competences. Therefore, this issue should also be considered in the linguistic context. We believe that at this point, it is appropriate to turn to research works by linguists (A. Avramenko, D. Danilchuk, S. Ermolenko, L. Masenko, V. Nimchuk, A. Ponomarev, I. Yushchuk and others).

It is important to note that linguistic competence has become the subject of study for a range of scholars. For example, E.D. Bozhovich (2016) believes that language competence is a system of knowledge about the language, the ability to use the language according to the speaker's (listener's) goals and the conditions of communication. In her study, N. Dyka (2017) explores the structure of linguistic competence. The scholar believes that this competence is based on the system of knowledge about language, language units of all levels (phonetic, lexical, word formational, morphological, syntactical). Foreign scholars have also investigated the formation of linguistic competence. For example, C. Paradis (2003) (Lund University, Sweden) says that competence is the result of 
our cognitive abilities.

It is important to mention that orthographic competence is an integral part of linguistic competence. However, there are very few studies dedicated to the problems of the formation of this competence in higher education institutions. The analysis of research works indicates that the factors that influence the formation of the competence have not been identified; the indicators of students' high skill in orthographic competence have been insufficiently developed; the opportunities for the students' self-education have not been defined or realized in this context.

The hypothesis of the study. The formation of the orthographic competence of future primary school teachers will be more efficient if:

- the factors that influence the formation of the professional competence of a future primary school teacher in the modern conditions are identified and considered;

- the competency-based, systemic and linguodidactic approaches become the theoretic-methodological foundation for the study;

- certain approaches are used as the basis for the model of orthographic literacy formation in future primary school teachers;

- the pedagogical conditions that facilitate the efficient operation of the model are identified.

There is no doubt that knowing orthographic rules and being able to apply them while writing are the universally accepted requirements for every modern person. One obtains key skills of correct written speech in general education schools. However, this knowledge is sufficient for certain groups of people. At the same time, there is a category of people for whom linguistic knowledge is the main working tool. Therefore, the requirements for the level of their written speech are substantially higher. Teachers who will develop the spelling skills of students are of particular significance among them. In this context, the knowledge level of the primary school teacher who will form the basis for students' correct spelling skills is the most important.

It is generally accepted that the presence of set norms in a language indicates its high level of development. Therefore, to know and observe these norms are the key requirements for a modern teacher. The orthographic norms are of primary significance among the language norms. It is important to stress that the orthographic norms are currently the subject of debate among Ukrainian scholars (Kulyk, 2007). It is worth noting that in May 2019, the Cabinet of Ministers of Ukraine adopted the resolution that approved the new version of the "Ukrainian spelling" (2019). The document was prepared by a specially created Ukrainian National Commission for Spelling, which included linguists well-known in Ukraine from the National Academy of Sciences and national universities from different regions of Ukraine. The norms and rules of the new edition of "Spelling" are recommended for application in all areas of public life (Kogut, 2019). However, the new spellings have begun to be used primarily only in educational institutions. In journalism and fiction, sometimes other spelling options are used. In this context, it seems significant to name the reasons for the existence of such orthographic pluralism, the consequences of which are reflected in students' speech today. Ukrainian spelling has repeatedly undergone certain changes (Bondar et al., 2006). In particular, during a certain period, the letter " $\Gamma$ " was eliminated from the Ukrainian alphabet (1933) and the rules of gender usage for some foreign words were changed. Moreover, several words that were part of the norm in the Ukrainian language were excluded from lexicographical sources. Those lexemes did not conform with the language policy of the time as they reflected the features of the Ukrainian language (Masenko, 2005). In the 1990s, the process of language restoration and the return of the "persecuted words" began. Moreover, the development of society gave rise to new notions which lead to the need to revise the spelling norms (Masenko, 2009). That is why in 1993, the new norms of Ukrainian spelling were adopted that were used in schools and higher education institutions. However, it was clear that the spelling required an update (Nimchuk, 2002). In this context, it seems important to mention the "The project of the newest version of Ukrainian spelling" that was developed under the leadership of the associate member of the National Academy of Sciences of Ukraine V. Nimchuk in 1999. The project was never officially approved (Nimchuk, 2010). Nevertheless, the publishers "Svitoch", "Letopis" and "Kritika" operate according to this standard and several Ukrainian writers use it in their works (O. Zabuzhko, Yu. Andrukhovich and others). Some points of this spelling standard are reflected in the broadcasts by the channel STB and other Ukrainian channels.

Therefore, one can conclude that Ukrainian students live under orthographic pluralism. There is no doubt that the radio, the press, in particular, the television and the Internet have a significant impact on modern young people. Thus, D. Danilchuk (2013) notes in his study, "After the introduction commercial (non-governmental) radio- and TV broadcasters in Ukraine, the issues of spelling also affected this sector of mass media landscape which has the largest audience" (p. 116). The scholar also notes that "As such giants of commercial television as " $1+1$ ”, ICTV, STB, "Novyi Kanal", "5 Kanal" and others gained access to nationwide Ukrainian coverage, each of them offered the audience their own view on the norms of the modern Ukrainian literary language" (Danilchuk, 2013, p. 116). Moreover, the same issue is relevant in publishing as editors come across a variety of orthographic norms. This situation, undoubtedly, affects the literacy of today's young people. The experiment was started to assess the state of the problem under investigation and, specifically, to establish the level of orthographic competence of future 
primary school teachers and whether it complies with the modern requirements.

\section{Methods}

In the study, theoretical and empirical methods were used. Within the framework of theoretical methods, analysis and synthesis of the literature on linguodidactics and modern Ukrainian literary language; an analysis of governmental documents on language-related education; an analysis of the content of textbooks and teaching aids on the Ukrainian language for students of pedagogical specialties of higher educational institutions; an analysis of the written speech of future specialists in the specialty "Primary education"; an analysis and synthesis of the best practices of scholars, teachers of philological subjects at pedagogical faculties of higher educational institutions were carried out. Students were assessed with the help of empirical methods (Cantos, 2013).

The logic of the study involved determining the features of the orthographic competence formation of future specialists. We understand the features of the competence formation as the complex of distinctive characteristics and patterns inherent only to this process. Thus, the following features of the orthographic competence formation were identified.

\subsection{The Basic Level of Knowledge in First-Year Students}

As pedagogical practice shows, most students who enter the first year have different levels of language training. It is important to note that due to economic, political and social problems in the state, the role of a modern teacher has partially lost its value. Therefore, the profession ranks very low among the prestigious specialties. That is why students with an average or sometimes even low level of knowledge primarily choose the specialty "Primary education". This means that among the modern community of students who have chosen the specialty "primary school teacher", there are few students with a high level of knowledge, in particular, of the Ukrainian language. Consequently, there is a need for high-quality linguistic training in the Ukrainian language within higher education institutions.

\subsection{The Particularity of Teacher-Student Cooperation}

The significant decrease in classwork when studying linguistic subjects within the specialty "Primary education".

First, the number of study hours in the course "Modern Ukrainian literary language" in the specialty "Primary education" has been reduced. Second, the subject "Practical Ukrainian spelling" is optional, which means that it is not compulsory. It is important to note that the aforementioned subjects are intended to form the orthographic competence in future primary school teachers, as the curriculum for the course "Modern Ukrainian literary language" (for "Primary education" students) features the section "Orthography". Within this section, students master the principles of Ukrainian spelling, orthographic norms and rules. However, due to the significant reduction in study hours, there is only one class intended for these topics or they are recommended for individual studies altogether.

\subsection{Educational and Methodological Support}

When (the previously mentioned) spelling inconsistencies occur, one should turn to lexicographical sources. However, there are some issues. First, the current "Ukrainian spelling" does not conclusively answer all the modern questions. Second, several orthographic dictionaries, including academic ones, require revision and reprinting. "Orthographic dictionaries issued by different authors differently interpret the aforementioned spelling issues or focus on alternative orthographic concepts (the same is true for many dictionaries-reference books on spelling, textbooks and teaching aids)" (Danilchuk, 2013, p. 6). Therefore, there is an issue of educational and methodological support that is particularly urgent in educational facilities.

The study was carried out based on the Mykolayiv National University named after V. Sukhomlinsky" (Nikolaev, Ukraine), the Faculty of Preschool and Primary Education. In total, there were 90 third-year and fourth-year full-time students in the specialty "Primary education". The choice of students of these years was due to the fact that during the previous years of studying, a cycle of linguistic disciplines was given to them, which corresponded to the curriculum of specialty 013 "Primary Education". As a result of training (first and second year), students should have a certain level of orthographic competence. In this context, it is important to determine the level of knowledge and practical skills in orthography for all future elementary school teachers, as in the future they will lay the foundation for orthographic literacy of the future generation. The study was conducted in stages.

At the first stage, the degree of investigation of this problem in scientific literature and pedagogical practice was determined. As a result, the requirements that society poses for modern primary school teachers were outlined. It was determined that the specialists will be the most successful in the labor market if they can set goals and achieve them, take part in life-long learning, work in teams, think critically, successfully communicate in a multicultural environment and use modern technologies. Consequently, the existing contradictions in the orthographic competence formation in future primary school teachers were identified. There are contradictions between the requirements set by the modern society for the 
primary school teacher and the lack of theoretical and methodological support that is used as the basis for the orthographic competence formation in future primary school teachers. The aforementioned contradictions defined the problem of the study: the modern theoretic and methodological support and the conditions of orthographic competence formation in future primary school teachers within higher education institutions.

The establishing stage of the experiment was carried out under regular conditions of the educational process in the pedagogical university. At this stage, the following goals were set: to assess the baseline of the orthographic competence of future primary school teachers; to define the directions for the formative stage of the experimental work. To achieve the goals of the establishing experiment, assessment methods were chosen: theoretical methods analysis and synthesis, empirical methods - conversation, testing, content analysis.

For the study, the criteria with the corresponding indicators were selected: cognitive (good command of theoretical material (knowledge of modern principles, norms and rules of orthography): completeness, thoroughness, soundness, awareness), praxeological (possession of practical skills, qualifications; ability to systematically and regularly apply theoretical knowledge when executing practical tasks), communicative-pragmatic (the ability to think critically, independently analyze the problem, find solutions).

Certain criteria and indicators were used to characterize the levels of orthographic competence in future primary school teachers: low, medium and high.

The high level is characterized by a deep level of knowledge of theoretical material. Students know modern orthographic principles, norms and rules, can regularly and systematically apply theoretical knowledge when carrying out practical tasks; are characterized by the presence of sustainable motivation for self-learning; can think critically; recognize, analyze problems; identify the contradictions that in modern spelling; have their point of view in the investigation of research issues.

The average level is characterized by an insufficient level of knowledge of theoretical material. Students do not systematically apply theoretical knowledge in practice, make spelling mistakes, are not fully able to independently carry out theoretical or empirical research, identify and critically interpret the problematic issues of modern Ukrainian orthography.

The low level is characterized by an insufficient level of knowledge of the basics of Ukrainian orthography. Students have not fully mastered orthographic skills. They are not able to regularly and systematically apply spelling knowledge when performing practical tasks, make spelling mistakes. Students of this level lack sustainable motivation for scientific research in the field of orthography; they cannot identify and interpret modern issues and contradictions of Ukrainian spelling.
At this stage, the participants of the control and experimental groups were chosen. The control group consisted of 45 students (third- and fourth-year full-time students in the specialty "Primary education"). The experimental group also consisted of 45 students (thirdand fourth-year full-time students in the specialty "Primary education"). This choice (particularly third- and fourth-year students) was determined by the fact that during the first and second years the students studied the courses "Practical Ukrainian spelling" and "Modern Ukrainian literary language".

The following methods were used to assess the levels of orthographic competence.

1. Conversation. Goal: To assess the level of knowledge of the problematic issues in modern orthography; to establish if the student can identify the contradictions in modern spelling; to find out if the student has an opinion on orthographic pluralism in Ukraine.

2. Testing (two types of tests): Test №1 (theoretical). This test contains questions on the history of the development of Ukrainian spelling; questions on knowledge of modern principles, norms and rules of Ukrainian orthography. Test №2 (practical). This test requires students to show that they can apply theoretical knowledge to practice. The test includes the main topics related to Ukrainian spelling (the use of the apostrophe, the soft sign, the alternation of sounds in the Ukrainian language, the spelling of prefixes and suffixes, the spelling of capital letters, the spelling of complex words, the spelling of foreign words).

3. Content analysis. Students should complete text-related tasks (write a dictation and a composition).

Table 1. Levels of orthographic competence in future primary school teachers (\%)

\begin{tabular}{|c|c|c|}
\hline Level & EG & CG \\
\hline Low & 44.4 & 46.7 \\
\hline Medium & 37.8 & 33.3 \\
\hline High & 17.8 & 20.0 \\
\hline
\end{tabular}

The results of the assessment of the orthographic competence that are reflected in the table indicated an insignificant discrepancy in the levels of the experimental (EG) and control (CG) groups (Table 1).

As a result of empirical research, it was established that the level of language training of future primary school teachers did not meet the modern requirements set by society (Table 1). From this, one can conclude that orthographic competence is not a natural result of classical training and requires special actions both by teachers and students. We believe that the main means of solving this problem is to create a model for the formation of this component of linguistic competence and implement it against the backdrop of a set of conditions. 
Based on the analysis and the generalization of the establishing experiment results, we established the pedagogical conditions of orthographic competence formation in future primary school teachers (Table 1). The first pedagogical condition is the formation of motivation in students to master orthographic competence. The second pedagogical condition is the utilization of modern pedagogical technologies in the linguistic training of future primary school teachers. The third pedagogical condition is the organization of the education process in higher education institutions in such a way that involves active student-teacher interaction, as well as a further joint productive activity.

In the second stage of the study, the model of orthographic literacy formation in future primary school teachers was developed based on the systemic and linguodidactic approaches (Fig. 1). The model consists of a set of blocks that are interconnected and interlinked.

The motivational-reflexive block involves the development of sustainable motivation to master a high level of orthographic literacy and, as a result, future teachers will recognize the importance of their profession (Fig. 1). This component of the model consists of two elements: personal identification and professional identification. To implement the first component of this block of the model, several training sessions were planned and conducted that were aimed at creating the professional identity, internal motivation and cognitive interests: "The role of the teacher in the modern world", "From the student to the teacher", "Self-image of a modern teacher". For this purpose, the problem group was formed called "The Ukrainian Language yesterday, today and tomorrow in Ukraine and the world". The work plan for the group was been developed that featured a series of round tables that were held: "Ukrainian studies outside the state" (the USA, Canada), "Ukrainian studies in Europe", "Ukrainian studies in Australia". At the round tables, students made reports, presentations and scientific projects in which they studied the functioning of the Ukrainian language outside Ukraine. Moreover, within the work of the problem group, the research seminars were held: "Ukrainian spelling systems of the 19th century: etymological and phonetic spelling”, "Ukrainian spelling 2019: problems and prospects". Group discussions were also held: "How important is the profession of a teacher in the modern world and why?", "What should a modern primary school teacher be like?”, "What kind of teacher am I?”. Group methods of work on such topics contribute to the development of professional introspection.

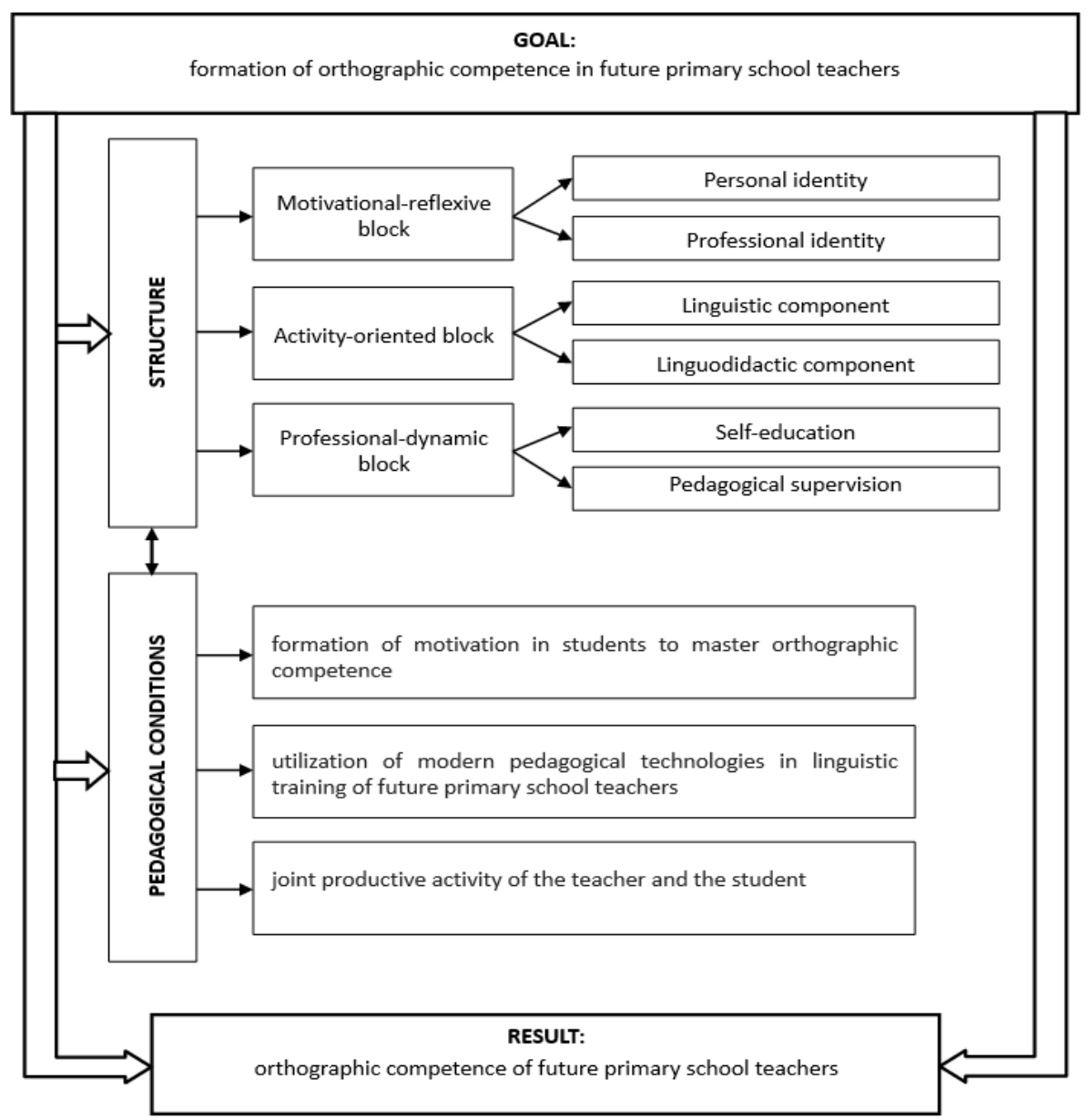

Figure 1. The model of orthographic literacy formation in future primary school teachers 
As a result of such work, students had the opportunity to realize the place of a teacher in the modern world, form an idea of themselves as teachers and people and develop a stable professional position.

The activity-oriented block of the model consists of two components: theoretical and practical (Fig. 1). The linguistic component involves professional language training for future primary school teachers. There is no doubt that the discussion of modern spelling trends and the analysis of existing rules are important for the formation of orthographic competency. In our opinion, this process will be more efficient within the classroom. It is extremely difficult to independently analyze the spelling issues that are the subject of discussion in modern society, respectively identify the problems of modern orthography and lexicography, and provide the views of famous linguists on these issues. Therefore, the subject and content of the lectures were changed. Historical materials were included, namely the issues of the formation and development of Ukrainian spelling. It is known that "over more than a thousand-year-old history of Ukrainian spelling, almost 50 different spelling systems were developed, within the framework of which the spelling rules were improved” (Bondar et al., 2006, p. 162). In this context, we offered students to study and discuss specific topics. First, in our opinion, the issues of the formation of Ukrainian spelling in the 19th century are relevant for understanding the current situation in spelling, namely: A. Pavlovskii's spelling, the system by M. Maksimovich historical-etymological spelling; the features of spelling of "Rusalka Dnestrovaya"; T. Shevchenko's spelling; spelling systems developed by prominent Ukrainian linguists: P. Kulish, M. Dragomanov, E. Zhelekhovskii. Second, the issue of the development of Ukrainian spelling in the 20th century remains significant today. In this case, together with students, we examined the question of creating a unified national spelling during the creation of Ukrainian statehood (1917-1919); spelling reforms of the first half of the twentieth century; "Ukrainian Spelling” of 1990 and its influence and the course of language discussions of that period. Third, at this stage, it is very important to analyze the problems and contradictions that exist in modern spelling. That is why we proposed the following topics for discussion by students: "Spelling 2019: major changes"; "Modern orthographic standards in science and journalism". Thus, in our opinion, working with such theoretical material helps to comprehend modern orthographic norms and rules and facilitates the understanding of the changes that occur in modern spelling.

The goals and objectives of this block are nevertheless aimed at active practical activity rather than theoretical. The linguodidactic component involves the use of modern pedagogical teaching technologies. At the lectures, we used the technology of problem-based learning, the technology of concentrated learning (involves a comprehensive study of the subject by combining classes into blocks), interactive technologies (interactive lecture, work with video and audio materials, work with visual aids, "student as a teacher", "everyone teaches everyone"). In practical classes, the following technologies were used: the technology of critical thinking; the brainstorming technology "reverse brainstorming", "double brainstorming", "conference of ideas", case study method. Also, the technology of the formation of the research activities for students was implemented (several scientific seminars were held, scientific papers were written).

To implement the goals and objectives of this block, control and certification technologies were also used. We consider it necessary to emphasize that it is important to apply the following types of control systemically and justifiably (this refers to written and oral control, frontal and individual, as well as selective, final and continuous control). At this point, it is necessary to indicate that the preferred method of knowledge assessment in higher education institutions is testing. There is no objection that this is one of the efficient methods of working with students. We developed and applied multilevel tests. However, in our opinion, in the context of checking the spelling, this method should not be predominant. Therefore, in practical classes, we used dictations, comprehensive reviews with various types of tasks and exercises. It is worth noting that we consider "exercises with keys" to be particularly useful. This type of work is efficient for both the student and the teacher. Students have the opportunity to find out whether the task is completed correctly, and the teacher can quickly check a large number of works.

The professional-dynamic block of the model consists of two components: self-education and pedagogical supervision (Fig. 1). This block is aimed at the formation of the skill of independent work in students; the development of the ability to systematically improve their professional level in the field of linguistics; the improvement of the skills of self-organization, introspection and self-control necessary to solve linguodidactic tasks in the process of professional activity. The implementation of the first component involves the creation of a set of teaching and methodological materials, video materials (accompanying lecture courses) for self-study of students. In this context, the technology of student research was used. Students were invited to investigate problematic issues (for example, the use of feminitives in the Ukrainian language in accordance with the new spelling; varied spelling in Ukrainian orthography, current norms, as well as other topics) and independently prepare presentations, reports, papers and research projects.

The implementation of the second component of the professional-dynamic block (pedagogical supervision) involved the analysis of the conscious and unconscious potential opportunities of future specialists; the provision of advisory assistance to future primary school teachers in overcoming professional difficulties in the explanation of 
spelling material during the Ukrainian language lessons (during pedagogical practice at school); the correction and the formation of their professional attitudes. Therefore, during the pedagogical practice at school and after, the following work was carried out: observation of the professional actions by the supervisor and other teachers, participation in the analysis of the lesson, joint planning of lessons, lessons taught by the teacher-supervisor. After the end of the practice, we used the following methods: clarifying observation (finding out the reasons for the professional problem of future teachers), focus analysis (studying the features of the professional difficulty of a particular student).

Therefore, the model allows one to realize the main goal of the study which is the formation of orthographic competence in future elementary school teachers in accordance with the modern requirements of society. The model makes it possible to determine all the structural elements of the pedagogical system in the process of the joint activity of students and teachers: content, pedagogical technologies, means of education, control methods.

\section{Results}

The formative experiment took place as part of the natural educational process at a higher educational institution (Table 2). After the establishing stage of the experiment (the first term), a special course "Modern Ukrainian spelling" was developed and introduced in the second term. In the CG, training was carried out according to the traditional curriculum without an emphasis on the formation of spelling competency. In the EG, certain pedagogical conditions were met, and the model developed for the formation of orthographic literacy in future primary school teachers was introduced (Fig. 1).

The analysis of the results showed that the number of EG students who had a high level of orthographic competency formation had significantly increased (from $17.8 \%$ to $33.3 \%$; the trend is $+15.5 \%$ ). The change in the average level result (from $37.8 \%$ to $46.7 \%$; the trend is $+8.9 \%$ ) was considered a positive result. This means that there were significantly fewer low-level students: at the establishing stage, there were $44.4 \%$ and as a result of the formative experiment, there were $20.0 \%$ (trend: $-24.4 \%$ ) (Table 2).

Thus, it was empirically proven that compliance with the proposed pedagogical conditions and the implementation of the constructed model contribute to the efficient formation of the orthographic competence in future primary school teachers.

\section{Discussion}

Foreign scholars' scientific works have particular significance for the analysis of the competence-based foundation of the linguistic competence formation in future primary school teachers. For example, the report "Learning: The Treasure Within" (2007) contains the key criteria and indicators of successful professional training of specialists who are directly linked to the competence-based approach to education. The European interpretation of competences (as the components of expertise) is laid out in the special document - "Key competences for Europe". This document was developed by G. Halasz and approved by the Council of Europe in 1996. The document takes into consideration the labor market requirements, economic features of European countries and other factors. Moreover, the paper defines five blocks of key competences for young Europeans: political and social; competences linked to living in a multicultural society; competences connected to verbal and written speech; informative competences; competences that involve an ability for life-long learning (Halasz, 2008).

The notion "linguistic competence" in relation to the language theory was proposed by Noam Chomsky (2005). One of the key topics in Chomsky's research was the desire to find explanations for two important facts - the creative usage of language by people and the wonderful phenomenon of language acquisition by children.

Table 2. The trend of the levels of orthographic competence in future primary school teachers according to the results of the establishing and formative stages of the experiment (\%)

\begin{tabular}{|c|c|c|c|c|c|c|}
\hline \multirow{2}{*}{ Level } & \multicolumn{3}{|c|}{ EG } & \multicolumn{3}{c|}{ CG } \\
\cline { 2 - 8 } & Establishing review & Control review & Trend & Establishing review & Control review & Trend \\
\hline Low & 44.4 & 20.0 & -24.4 & 46.7 & 42.2 & -4.5 \\
\hline Average & 37.8 & 46.7 & +8.9 & 33.3 & 35.6 & +2.3 \\
\hline High & 17.8 & 33.3 & +15.5 & 20.0 & 22.2 & +2.2 \\
\hline
\end{tabular}


In Europe, competence is mainly equated to abilities, personal traits and acquired knowledge. The prevailing opinion in Great Britain is that competence should be defined as the compliance of an individual's activity to certain standards. Scholars are trying to build an activity-oriented model as opposed to the technically rational approach. The linguistic course is of particular significance in the training of teachers of Germany, France, Italy, Denmark, Great Britain and other countries. For example, in Spain, like in other European countries, there have been changes in education. Consequently, special attention is paid to the formation of key competencies and the corresponding skills in the training of students-future primary school teachers. It is worth noting that teachers in Spanish higher education institutions agree that it is very important to develop students' linguistic competence that is closely connected to the level of language training of primary school teachers (Ezquerra, 2014).

As a result of the study, it was established that there are modern research works dedicated to different aspects of teachers' linguistic training for professional activity. However, there are very few fundamental comprehensive studies on the issue of orthographic competence formation of future teachers.

\section{Conclusions}

There are no doubts that orthographic literacy is a definitive indicator of the high level of training in future primary school teachers. However, the issue of future specialists' orthographic competence is still quite urgent. Undoubtedly, the high-quality linguistic training of teachers is not defined solely through this component. We believe that modern realities require a reform in the higher education system. This would require further research into the level of linguistic training of future specialists in the field "Primary education" in Ukraine. It is important to note that this work does not claim to provide exhaustive solutions to all problems related to improving the orthographic competence of pedagogic university students. This matter should be undoubtedly presented for a wider discussion. After all, these specialists will be building the foundations of the orthographic literacy of the future generation. That is why the modernization of the system of pedagogical education in Ukraine is necessary. In this context, it seems relevant to define such a development path that would bring the level of Ukrainian education up to European standards. However, one should not neglect all the achievements and experience of Ukrainian pedagogy in higher education.

\section{REFERENCES}

[1] Bondar, A. I., Karpenko, A., \& Nikitin-Druzhinets, M. L.
(2006). Sovremennyi ukrainskii yazyk: Fonetika. Fonologiya. Orfoepiya. Grafika. Orfografiya. Leksikologiya. Leksikografiya: ucheb. posobie [The modern Ukrainian language: phonetics, phonology, orthoepy, writing system, spelling, lexicology. Lexicography: a textbook]. Kiev: VTs "Akademiya".

[2] Bozhovich, E. D. (2016). Razvitie yazykovoi kompetentsii kak psikhologicheskoi sistemy [The development of linguistic competence as a psychological system], Dissertation for the Degree of the Doctor of Psychological Sciences, Moscow.

[3] Cantos, G. P. (2013). Statistical methods in language and linguistic research. Sheffield: Equinox.

[4] Chomsky, N. (2005). Cartesian Linguistics: A Chapter in the History of Rationalist Thought. Moscow: KomKniga.

[5] Danilchuk, D. V. (2013). Ukrainskoe pravopisanie: pereputya i ukazateli [Ukrainian spelling: crossroads and road signs]. Kiev: Lybid.

[6] Delors, J. (2007). Obrazovanie: sokrytoe sokrovishche [Learning: The Treasure Within)], Highlights of the report of the International Commission on Education for the Twenty-first Century. Online available fromhttp://www.ifap.ru/library/book201.pdf

[7] Dyka, N. M. (2017). Formirovanie yazykovoi lichnosti uchenika obshcheobrazovatelnogo uchebnogo zavedeniya v usloviyakh realizatsii kontseptsii novoi ukrainskoi shkoly [Formation of the linguistic personality of students in general education facilities during the implementation of the concept of the new Ukrainian school]. Scientific journal “Molodoi uchenyi”, 11(51), 294-297.

[8] Ezquerra, A. (2014). Teachers' Opinion about Teaching Competences and Development of Students' Key Competences in Spain, Procedia Social and Behavioral Sciences.

[9] Halasz, G. (2008). A rewarding challenge. How the multiplicity of languages could strengthen Europe: Proposals from the Group of Intellectuals for Intercultural Dialogue setup at the initiative of the European Commission. Online available from https://ec.europa.eu/education/sites/e ducation/files/rewarding-challenge-report_en.pdf

[10] Kogut, V. M. (2019). Ukrainskoe pravopisanie 2019: Izmeneniya i pravila [Ukrainian spelling 2019: changes and rules]. Ternopol: Uchebnaya kniga, Bogdan.

[11] Kulyk, V. (2007). The demography of language practices and attitudes in Ukraine. Harvard Ukrainian Studies, 29(1/4), 295-326.

[12] Masenko, L. (2005). Ukrainskii yazyk v XX stoletii: istoriya lingvotsida: dokumenty i materialy [The Ukrainian language in the 20th century: a history of linguicide: documents and materials]. Kiev: Izd. dom "Kievo-Mogilyanskaya akademiya”.

[13] Masenko, L. (2009). Language situation in Ukraine: Sociolinguistic analysis. In J. Besters-Dilger (ed.), Language Policy and Language Situation in Ukraine, 101-137. Frankfurt am Main: Peter Lang.

[14] Nimchuk, V. (2002). Problemy ukrainskogo pravopisaniya XX - nachala XXI v. [Issues in Ukrainian spelling at the turn 
of the 20th century]. Kiev: NAN Ukrainy, In-t ukrainskogo yazyka.

[15] Nimchuk, V. (2010). Proekt ukrainskogo pravopisaniya [Ukrainian spelling project]. Online available from https://r2u.org.ua/pravopys/pravXXI/zmist.htm\#proekt

[16] Paradis, C. (2003). Is the Notion of Linguistic Competence at All Relevant in Cognitive Linguistics? Annual Review of
Cognitive Linguistics, 1(1), 207-231.

[17] Rashkevich, Yu. M. (2014). Bolonskii protsess i novaya paradigma vysshego obrazovaniya: monografiya [The Bologna process and the new paradigm of higher education]. Lvov: Izdatelstvo Lvovskoi politekhniki.

[18] Ukrainskoe pravopisanie [Ukrainian spelling]. (2019). Novaya redaktsiya: Nauchnaya mysl. 